\title{
Credit Constraints and the Productivity of Small and Medium-sized Enterprises: Evidence from Canada
}

\section{Mark Lim ${ }^{1 \rtimes}$ \\ Jessica Foster ${ }^{2}$ \\ ${ }_{1,2}^{1,}$ University of Ottawa, Canada. \\ Email:mark.lim@uottawa.ca}

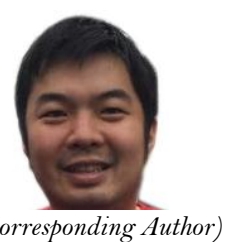

( Corresponding Author)

\begin{abstract}
Small and medium-sized enterprises (SMEs) are regulators of the business environment. In Canada, SMEs represent about 50 percent of businesses and are responsible for over 60 percent of the country's employment. The role of SMEs in the development of a country can't be ignored, as they are vital indicators of economic development. The size and cash flow of a company's assets are reliable indicators of credit constraints $(\mathrm{CC})$, which results in a $\mathrm{CC}$ agent for models that use an asset-to-liability ratio. We focus on the actual impact of a previously estimated score in cases where corporate credit is limited. Investment and employment decisions are based on productivity shocks (PS) and the possibility of CC. Using variables, our model indicates the importance of measured credit restrictions being distinguished, such as cash flows that indicate productivity levels and the probability of CC. The data samples are from 2009 to 2014, although the measurement of $\mathrm{CC}$ is only available from 2011. Therefore, we use the model of credit constraint estimation to anticipate the likelihood of $\mathrm{CC}$ in the months before and after 2011. The findings reflect that the firm's size, debt to assets ratio, and cash flow are significant factors in the evaluation of the CC, whereas long-term debt (LTD) to asset ratio wasn't found to be significant. The study also evaluates and estimates firm-level productivity.
\end{abstract}

Keywords: Credit Constraints; Productivity; Canada.

Citation | Mark Lim; Jessica Foster (2020). Credit Constraints and the Productivity of Small and Medium-sized Enterprises: Evidence from Canada. Asian Journal of Economics and Empirical Research, 7(2): 178-185.

History:

Received: 20 May 2020

Revised: 23 June 2020

Revised: 23 June 2020

Published: 17 August 2020

Licensed: This work is licensed under a Creative Commons Attribution 3.0 License (cc) I E

Publisher: Asian Online Journal Publishing Group
Acknowledgement: All authors contributed to the conception and design of the study.

Funding: This study received no specific financial support.

Competing Interests: The authors declare that they have no conflict of interests.

Transparency: The authors confirm that the manuscript is an honest, accurate, and transparent account of the study was reported; that no vital features of the study have been omitted; and that any discrepancies from the features of the study have been omitted;
study as planned have been explained.

Ethical: This study follows all ethical practices during writing.

\section{Contents}

1. Introduction

2. Literature Review ...

3. Data Collection

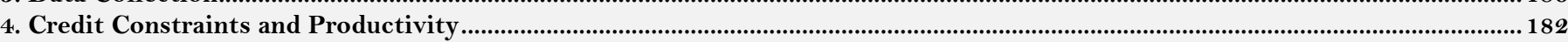

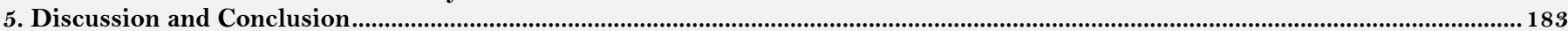

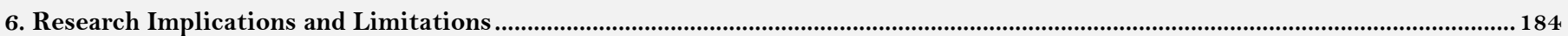

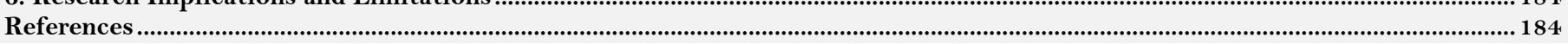




\section{Contribution of this paper to the literature.}

This research paper makes two important and constructive contributions towards effectively understanding and forecasting financial constraints (FC), such as sales growth and LTDs, as well as their direct impacts on the performance level of the firm. First, the present study adds to existing research on $\mathrm{CC}$, specifically in relation to small businesses. To our knowledge, the present research is the first to analyze FC in SMEs independently from examined outcomes and results of EF. Second, the following study significantly contributes to effectively forecasting the relationship between FC and productivity at an organizational level, which is mainly based on productivity measurements and a consideration of FC.

\section{Introduction}

Credit constraints (CC), which can be determined through an evaluation of the activities and outcomes of a firm and its external financing (EF) (Dubé, Brunelle, \& Legros, 2016), result in a reduction in the rate of productivity of SMEs of Canada, in comparison to larger organizations. Organizations that achieve high levels of productivity and compatibility and use innovative technology are less likely to face the problem of financial constraints (FC) (Ramkissoon \& Mavondo, 2017). Therefore, SMEs in Canada should overcome the issue of FC so that their productivity can increase, which will provide better results and products for customers. Several characteristics of an organization can act as an alternative to determining the $\mathrm{CC}$ of a firm, which helps to discover the firm's needs in terms of EF (Calic, Shevchenko, Ghasemaghaei, Bontis, \& Tokcan, 2020). The general phenomenon of credit and $\mathrm{CC}$ has been gaining considerable attention from academic practitioners and analysts over the last few years (Chatterjee, Karray, \& Sigué, 2019). However, it has been noted that, even now, a performance and overall presentation gap exists in SMEs; although a large number of SMEs perform as successful businesses, their growth is lower than other businesses in this sector. Rose (2016) has suggested that, in order to address this productivity and exclusive performance gap, the significant contextual variables affecting the intentions of SMEs need to be investigated in detail, as existing research on CC and its impacts on SMEs and their performance are limited. Therefore, studies needs to be conducted on SMEs in certain countries and regions (Ortiz-de-Mandojana \& Bansal, 2016); Kraja (2018) in order to evaluate the impact of certain tangibles (Buallay, Hamdan, and Zureigat, 2017), investigate the overall impact of corporate governance, and (Al-Haddad, Taleb, and Badran (2018) evaluate the impact of growth and tangibility on the productivity of SMEs. Hence, understating CC and its impact on overall levels of productivity in SMEs and other firms is important in order to address the gaps in academic studies. The current study explores the impact of CC on the performance and productivity of SMEs.

The above discussions and justification statement have guided the development of the following objectives and purposes. The main aim of this study is to investigate the exclusive impact of CC on productivity levels in SMEs in Canada, including sales growth, total assets, and long-term debt (LTD). The given study also computes the likelihood of a business being constrained by credit and other factors, as well as analyzing observed outcomes and the results of EF. Moreover, the current paper is associated with research on measuring and quantifying the significance of financial variables and how they influence factual variables, such as productivity, investment, and employment levels.

This research paper makes two important and constructive contributions towards effectively understanding and forecasting financial constraints (FC), such as sales growth and LTDs, as well as their direct impacts on the performance level of the firm. First, the present study adds to existing research on $\mathrm{CC}$, specifically in relation to small businesses. To our knowledge, the present research is the first to analyze FC in SMEs independently from examined outcomes and results of EF. Second, the following study significantly contributes to effectively forecasting the relationship between $\mathrm{FC}$ and productivity at an organizational level, which is mainly based on productivity measurements and a consideration of $\mathrm{FC}$.

This research paper has deep benefits and advantages both in practice and in theory. Theoretically, the paper contributes to the current body of data on variables that affect productivity levels in firms, and practically, the findings and suggestions of this paper are beneficial for academic scholars and policymakers. The remainder of the paper will be organized as follows: In the second chapter, the analyst will review relevant literature; in the third chapter, the analyst will estimate and measure the extent to which SMEs are restricted by EF; in chapter four, the analyst will measure the extent to which investment and employment development are influenced by FC, capacity, and productivity; and in chapter five, the analyst will conclude the findings of the study.

\section{Literature Review}

Although several theories on FC have emerged, most of the models and frameworks focused on understanding the constraints on business firms and organizations (Wetzel \& Hofmann, 2019). According to Bolton (2016), constraints have just as much of an impact and significance on the overall finances of a business, and expertly trained financial advisors play a crucial role in helping businesses and clients to understand the constraints and restrictions of their business objectives. According to this theory, FC limit certain economic actions and productivity levels in businesses, and according to Dinopoulos, Kalyvitis, and Katsimi (2020), they must be accommodated. For instance, a broker may restrict an SME from short selling, margin trading, and other options that may limit an SME's investment, which will influence the productivity of the firm. This theory also states that $\mathrm{FC}$ are specific and objective obstacles and restrictions, as opposed to being typical and subjective (Dasgupta, Li, \& Yan, 2017). According to Bilal, Khan, and Akoorie (2016), FC refer to any factors that limit the amount and quality of investment options for investors. Every business and SME faces both internal and external constraints (Miao \& Wang, 2018), such as a lack of knowledge or information and an insignificant cash flow. Furthermore, this theory states that regulations and policies exert restrictions on the profitability level of businesses. These constraints range from governmental limitations on imports and exports, conditional limitations that manage materials used, to certain policies that must be accomplished. Generally, their influence on development can be strengthened.

Financial factors and variables are common constraints for businesses and SMEs, and according to this theory, they range from insufficient budget allocations or distributions to excessive payments and overhead expenditures (Eapen, Yeo, \& Sasidharan, 2019). For example, if a business does not have the capital to buy more stock, its ability 
to sell is a constraint that affects its overall business performance. Similarly, if more staff are needed but the budget cannot accommodate additional payments, the entire growth of the business will be limited.

\subsection{Credit Constraints and the Productivity Level of SMEs}

According to Li, Liao, and Zhao (2018), CC is the factor that businesses must confront in order to implement its business strategy, as each business has its own particular combination of constraints and limitations that collectively impact its competitive position and image within its sector. According to Jin, Zhao, and Kumbhakar (2019), SMEs are essentially a way to ensure that assets work overtime, as physical assets typically depreciate with time and credit tends to decrease in value, mainly due to inflation. In comparison, investments in competitive business environments have a remarkable predisposition to increase in value over credit and time. In order to execute this remarkable feat, SMEs and different firms must maintain productive assets and continually implement new processes and practices to stay competitive. As such credit is essential, certain limitations that enable credit to be used more efficiently, such as credit management and other significant practices, are basic management considerations. Moreover, according to Altomonte, Gamba, Mancusi, and Vezzulli (2016), assets are an important form of $\mathrm{CC}$, encompassing all intangible resources that contribute to the future cash flow and productivity of an SME. An effective example of an asset-related constraint, according to Choi, Furceri, Huang, and Loungani (2018), is a slow piece of equipment on a production line that directly influences the entire productivity of a business. Any current assets, including property, IP, equipment, represent constraints that significantly influence the productivity of a business. According to Cao and Leung (2019), liquid assets such as investments and cash are a particular constraint that directly influences the productivity of the business, as cash is critical to pay for operating costs and other payments. If a firm runs out of cash, everything related to productivity tends to collapse. Fast sales growth (SG) and development can be both an advantage and disadvantage for many firms, as it generates the potential for greater profit and productivity while demanding more cash to support significant growth (Bokpin, Ackah, \& Kunawotor, 2018). As described by Aghion, Bergeaud, Cette, Lecat, and Maghin (2019), the influence of SG on the balance sheet and productivity is considerable, specifically in terms of business inventory checks and accounts receivable because these trading assets are necessary for the SME's financial and operating cycle. In the simplest terms, SMEs start with capital and then they purchase materials and equipment that are processed, manufactured, sold, distributed and finally converted to cash. Not only does this influence the liquidity of the SME, but, according to Hasan and Sheldon (2016), it also directly influences and impacts the productivity of business level conversations. SG significantly affects the productivity of SMEs in several ways; for those reliant on a significant number of smaller suppliers, it increases their liquidity, which may allow them to ensure the best contractors on constructive terms or rapidly enhance their supply base over a short period of time, in order to respond to market needs and requirements (Yang, 2018). In contrast, SMEs that predominantly need to make considerable investments in property, people and equipment to support major initiatives may have much simpler needs exclusive of essential liquidity; therefore, essential investments cannot be generated, or must be scaled back, perhaps to the degree that leads to certain missed opportunity (Ganau, 2016).

The LTD of an organization increases the need for EF, which, in turn, leads to an increase in the rate of productivity, especially in small firms in Canada because they have fewer CC. Research by Dörr, Raissi, and Weber (2018) has stated that the operations of a firm can be expanded as a result of LTD, and it also allows small enterprises to gain access to the financial sector. Bannerman and $\mathrm{Fu}(2019)$ explain the fact that, if an organization has access to LTD finance, it becomes possible for the organization to spend money on equipment and innovative capital, which helps it to increase its rate of productivity. It also allows organizations to invest in innovative techniques, tools, machinery, and technology so that effective products can be produced. The theory of FC proves that a lack of knowledge and insignificant cash flow can cause a decrease in an organization's productivity. Hasan., Kobeissi, Liu, and Wang (2018) confirmed a direct relationship between productivity levels and LTD, as an increase in one variable results in a decrease in the other, and vice versa.

\section{Data Collection}

Data was collected from SMEs operating in Canada. SMEs employ between 50-500 people and are responsible for more than 50 percent of the output generated by the business sector (Rispoli, Leung, \& Baldwin, 2013). Data was acquired from the Survey on Financing of Small and Medium-sized Enterprises (SFSME), in addition to other experimental data. The SFSME maintains a cross-sectional database of Canadian businesses that employ less than 500 workers and have a reported profit of less than 50 million dollars. The database provides details and information on the firm's petition for financing, the reasons why loan requests are terminated, the loan utility process, the interest rate of the loan, the type of interest (compounded, simple, annual, biannual), the collaterals used for securing the loan position, and whether or not the loan amount is ensured by the government. The database also offers information with regard to the equity financing, leasing, and governmental financing properties of the SMEs. The data is formally available for 2004, 2007, 2011. The administrative sources provide information on SFSME firms using financial statements. For the purposes of this study, the data from 2011 have been used; however, the financing activities from 2007 are also reported. The data is based on SFSME survey results.

\subsection{Measurement of Credit Constraints}

As the measurements of $\mathrm{CC}$ are only available for 2011 , characteristics and estimations are being calculated for that year (Moscalu, Girardone, \& Calabrese, 2019). In order to assess CC probability in the years before and after 2011, the model of CC estimation was used. Foreign financing is unconditional, as it is safer than in 2011. In order to make sure that Chinese SMEs will be financially restricted, scores have been assigned according to their knowledge of activities and outcomes. This is less likely to occur in high-scoring companies. Companies report whether they have applied for SFSME data (Bena \& Jurajda, 2011). The types of financial instruments include long-term loans, lease financing, government grants, equity, trade credit, and short-term loans. 
The values given in parentheses indicate the robust standard errors; $(*)$ indicates the importance of coefficients at a degree of $10 \%$; (**) indicates a level of $5 \%$; and $(* * *)$ indicates a level of $1 \%$ for $\mathrm{P}$ values. Table 1 reports the main results of the estimated measured FC as a function of the characteristics of the firm. The "Full Model" column reports Probit estimations using a sample selection, the "FC" column reports the probability of three degrees, and the "Needfin" column reports the estimations of the sample selections. In this paper, the reasons for not requesting $\mathrm{EF}$ are also reported, with many companies stating they do not need EF and others stating that EF is expensive. The measured CC only refers to the observed EF results; our scale does not differentiate between companies with high levels of debt and companies in financial difficulty. The debt-to-asset ratio is useful, but it cannot be obtained (Guiso, Jappelli, Padula, \& Pagano, 2004). Demand may vary from one sector to another, as a result of certain sectors acquiring a great increase in productivity. Financial restrictions do not depend on the sector of each company.

\subsection{Selection of Credit Constraints}

The age and size of a firm are important factors to consider when identifying CC, which is why they are often used in the literature. The estimated values show that large companies have CC if they need EF support (Lucey, Zhang, \& Finance, 2011). In Table 2, the "MLC" column refers to the most likely constraints and the "LC" column shows the likely constrains. According to the collateral constraint model, large companies can use more guarantees to obtain EF, so they are more likely to apply for credit; if they do, their results are less likely because they provide more collateral results. In companies, the marginal effects of the size of the assets are, most probably, both negative and statistically significant, as shown in Table 2. Negative marginal effects appear when the company is ten years old or older, but the statistics are only important when the company is twenty years old or older. To summarize the findings of the estimations of the inclusion of $\mathrm{CC}$, it can be stated that proxy variables such as the size and age of the firm, cash flow, and the current debt and dividend levels are effective constraints in the evaluation of SMEs.

\begin{tabular}{|c|c|c|c|c|}
\hline Variables & Full Model & & $(2)$ & $(3)$ \\
\hline & $\mathrm{FC}$ & NeedFin & $\mathrm{FC}$ & $\mathrm{FC}$ \\
\hline \multirow[t]{2}{*}{ Long-term debt/assets } & 0.009 & $-0.200 * *$ & 0.075 & 0.052 \\
\hline & $(0.042)$ & $(0.046)$ & $(0.049)$ & $(0.039)$ \\
\hline \multirow[t]{2}{*}{ Current Debt/Assets } & $0.165 * * *$ & $0.253 * * *$ & 0.08 & $0.090 * * *$ \\
\hline & $(0.048)$ & $(0.063)$ & $(0.057)$ & $(0.054)$ \\
\hline \multirow[t]{2}{*}{ Sales Growth } & -0.006 & 0.102 & -0.04 & 0.044 \\
\hline & $(0.047)$ & $(0.075)$ & $(0.072)$ & $(0.033)$ \\
\hline \multirow[t]{2}{*}{ Current Assets/Assets } & -0.629 & 0.715 & -0.767 & -0.1 \\
\hline & $(1.262)$ & $(1.354)$ & $(1.455)$ & $(1.485)$ \\
\hline \multirow[t]{2}{*}{ Cash flow/Assets } & $-0.211 * * *$ & $-0.128 * * *$ & $-0.193 * * *$ & $-0.201 * * *$ \\
\hline & $(0.056)$ & $(0.033)$ & (0.069) & $(0.047)$ \\
\hline \multirow[t]{2}{*}{ In (Assets) } & $-0.201 * * *$ & $0.134 * *$ & $-0.271 * * *$ & -0.086 \\
\hline & $(0.012)$ & $(0.060)$ & $(0.057)$ & $(0.058)$ \\
\hline \multirow[t]{2}{*}{$1\{$ Dividend $>0\}$} & $-0.192 * * *$ & -0.01 & $-0.200 * * *$ & $-0.152 * *$ \\
\hline & $(0.069)$ & $(0.048)$ & $(0.072)$ & $(0.067)$ \\
\hline \multirow[t]{2}{*}{$3<$ Age $<=5$} & 0.086 & -0.021 & 0.081 & 0.053 \\
\hline & $(0.054)$ & $(0.081)$ & $(0.062)$ & $(0.082)$ \\
\hline \multirow[t]{2}{*}{$5<$ Age $<=10$} & $0.188 * * *$ & 0.002 & $0.176 * *$ & $0.136 * *$ \\
\hline & $(0.029)$ & $(0.069)$ & $(0.075)$ & $(0.048)$ \\
\hline \multirow[t]{2}{*}{$10<$ Age $<=15$} & 0.009 & $-0.200 * *$ & 0.075 & 0.052 \\
\hline & $(0.042)$ & $(0.046)$ & $(0.049)$ & $(0.039)$ \\
\hline \multirow[t]{2}{*}{$15<$ Age $<=20$} & $-0.201 * * *$ & $0.134 * *$ & $-0.271 * * *$ & -0.086 \\
\hline & $(0.012)$ & $(0.060)$ & $(0.057)$ & $(0.058)$ \\
\hline \multirow[t]{2}{*}{$20<$ Age $<=25$} & $-0.192 * * *$ & -0.01 & $-0.200 * * *$ & $-0.152 * *$ \\
\hline & $(0.069)$ & $(0.048)$ & $(0.072)$ & $(0.067)$ \\
\hline \multirow[t]{2}{*}{$25<$ Age } & 0.086 & -0.021 & 0.081 & 0.053 \\
\hline & $(0.054)$ & $(0.081)$ & $(0.062)$ & $(0.082)$ \\
\hline \multirow[t]{2}{*}{$3<$ Age $<=5$}$*$ In (assets $\}$ & $0.188 * * *$ & 0.002 & $0.176 * *$ & $0.136 * *$ \\
\hline & $(0.029)$ & $(0.069)$ & $(0.075)$ & $(0.048)$ \\
\hline \multirow[t]{2}{*}{$5<$ Age $<=10$}$*$ In (assets $\}$ & 0.009 & $-0.200 * *$ & 0.075 & 0.052 \\
\hline & $(0.042)$ & $(0.046)$ & $(0.049)$ & $(0.039)$ \\
\hline \multirow[t]{2}{*}{$10<$ Age $<=15$}$*$ In (assets $\}$ & $0.165 * * *$ & $0.253 * * *$ & 0.08 & $0.090 * * *$ \\
\hline & $(0.048)$ & $(0.063)$ & $(0.057)$ & $(0.054)$ \\
\hline \multirow[t]{2}{*}{$15<$ Age $<=20$}$*$ In $($ ssets $\}$ & 0.086 & -0.021 & 0.081 & 0.053 \\
\hline & $(0.054)$ & $(0.081)$ & $(0.062)$ & $(0.082)$ \\
\hline \multirow[t]{2}{*}{$20<$ Age $<=25$}$*$ In (assets $\}$ & $0.188 * * *$ & 0.002 & $0.176 * *$ & $0.136 * *$ \\
\hline & $(0.029)$ & (0.069) & $(0.075)$ & $(0.048)$ \\
\hline
\end{tabular}




\begin{tabular}{l|c|c|c|c}
\hline & \multicolumn{2}{|c|}{ MLC } & \multicolumn{2}{c}{ LC } \\
\cline { 2 - 5 } & Standard Error & $\boldsymbol{d y} / \boldsymbol{d} \boldsymbol{x}$ & Standard Error & $\boldsymbol{d y} / \boldsymbol{d} \boldsymbol{x}$ \\
\hline In Assets & 0.002 & -0.016 & 0.002 & -0.013 \\
\hline Business Age $<=3$ & 0.023 & 0.021 & 0.023 & 0.020 \\
\hline Business Age $>25$ & 0.020 & -0.027 & 0.018 & -0.021 \\
\hline Cashflow/Assets & 0.008 & 0.028 & 0.013 & 0.028 \\
\hline Long-term debt/assets & 0.006 & 0.000 & 0.007 & 0.000 \\
\hline Current Assets/Debt & 0.011 & -0.037 & 0.011 & -0.036 \\
\hline
\end{tabular}

\section{Credit Constraints and Productivity}

The main influence of $\mathrm{CC}$ lies in the fact that they can affect the growth of a firm by hindering and limiting the ability of the firm to make decisions in terms of investment and recruitment. These decisions are also dependent on the overall productivity of the firm, which will be estimated. The total-factor productivity (TFP) of the firm is estimated using a structural procedure that is fixated on the production level of firms, as discussed by Olley and Pakes (1992). An extended version of their suggested method has been followed in the present study. In much of the previous empirical literature, the estimation of the production function was abstracted from the CC, while the control factors of employment and investment were found to be functions of a firm's ability to finance and acquire TFP. Therefore, these factors will not be omitted, and the method of inclusion has been updated. As suggested by Ackerberg, Caves, and Frazer (2015), an estimation of production function was carried out, so that the CC can be taken into consideration. The TFP was then used as an independent variable so that its likelihood to be constrained could also be calculated. This process allows for the evaluation of the relationship between productivity and CC. The process of productivity is assumed to take the following form:

$$
\begin{array}{r}
\omega_{j t}=g\left(\omega_{j t}, x_{j t-1}, f_{j t-1}^{c}\right)+\xi_{j t} \\
=\sum_{j=0}^{3} \gamma i\left(\omega_{j t-1}\right)^{i}++\gamma_{4} f_{j t-1}^{c}+\gamma_{5} x_{j t-1}++\gamma_{6} f_{j t-1}^{c} x_{j t-1}++\xi_{j t}
\end{array}
$$

In the case that $\gamma_{4}=\gamma_{5}=\gamma_{6}=0$, the term $\omega_{j t}$ is presumed to be exogenous. The endogenous component of the productivity is determined by the investments and measures of the $\mathrm{CC}$, which are considered for both lagged and level periods. Lagged investments can impact a firm's productivity through innovation and other value additions.

\subsection{Production Function Estimations}

First, the correlation between productivity estimates and $\mathrm{FC}$ were evaluated in order to understand whether or not they were related. For the estimation process, lagged labor, capital, and the square of lagged labor were considered to be instrumental to the calculation. The estimates of the parameters are defined in the Table 3. The first row of the table summarizes and presents results calculated using the ordinary least squares (OLS) method, the second row assumes that $\gamma_{4}=0$, and the third row shows the estimations of the endogenous $\operatorname{TFP}\left(\gamma_{4} \neq 0\right)$. The last two rows in Table 3 display the estimations of the TFP and CC. The exogenous productivity estimates were found to be greater than the estimates when they were evaluated after omitting the FC. This result was expected, as the correlation coefficient among the production factors and the $\mathrm{CC}$ was negative. In terms of production capacity, the capacity of labor and capital was more significant than estimated, excluding EF and FC. This was also to be expected, as productivity factors and $\mathrm{CC}$ were negatively correlated when a two-stage generalized methods of moments (GMM) was estimated to include CC. When increased, the real relationship between total input and productivity was restored, which resulted in an increased growth in labor. For example, due to borrowing restrictions, a manufacturing firm observed a low wage input compared to other firms with the same total production level.

\begin{tabular}{|c|c|c|c|c|c|}
\hline \multicolumn{2}{|l|}{$\hat{\boldsymbol{a}_{1}}$} & Std. Err. & $\hat{\boldsymbol{\alpha}_{k}}$ & Std. Err. & RHS vars. in TFP shock proces: \\
\hline \multicolumn{2}{|c|}{ (i) No financing decisions } & 0.007 & 0.048 & 0.003 & - \\
\hline \multicolumn{2}{|c|}{ (ii) No financing decisions } & 0.165 & 0.053 & 0.012 & - \\
\hline 2-stage, endo & 0.632 & 0.092 & 0.051 & 0.008 & $X j t-1$ \\
\hline \multicolumn{2}{|c|}{$\begin{array}{l}\text { (iii) With, but without financial constrain } \\
\text { 2-stage, exog } \quad 0.664\end{array}$} & 0.194 & 0.056 & 0.012 & - \\
\hline 2-stage, endo & 0.637 & 0.205 & 0.055 & 0.012 & $f c j t-1$ \\
\hline 2-stage, endo & 0.622 & 0.202 & 0.055 & 0.012 & $f c j t-1, X j t-1, f c j t-1 * X j t-1$ \\
\hline $\begin{array}{l}\text { (iv) With financial } \\
\text { 2-stage, exog }\end{array}$ & $\begin{array}{c}\text { constraint } \\
0.663 \\
\end{array}$ & 0.102 & 0.058 & 0.012 & - \\
\hline 2-stage, endo & 0.682 & 0.360 & 0.062 & 0.021 & fcjt-1 \\
\hline 2-stage, endo & 0.671 & 0.270 & 0.062 & 0.012 & $f c j t-1, X j t-1$ \\
\hline 2-stage, endo & 0.671 & 0.258 & 0.062 & 0.011 & $f c j t-1, X j t-1, f c j t-1 \cdot X j t-1$ \\
\hline 2-stage, endo & 0.642 & 0.234 & 0.056 & 0.012 & $\begin{array}{c}f c j t-1, X j t-1, f c j t-1 \cdot X j t-1, f c j t-1 \\
\omega j t^{-1}\end{array}$ \\
\hline
\end{tabular}

Table 3. Estimates of the parameters 
Table 4. Estimations of the impact of TFP on credit

\begin{tabular}{|c|c|c|c|c|}
\hline & (1) $\mathrm{FC}$ & Need Fin & (2) $\mathrm{FC}$ & Need Fin \\
\hline \multirow[t]{2}{*}{ Current debt/Assets } & $0.185^{* * *}$ & $0.273^{* * *}$ & $0.182^{* *}$ & $0.288^{* * *}$ \\
\hline & $(0.056)$ & $(0.043)$ & $(0.072)$ & $(0.053)$ \\
\hline \multirow[t]{2}{*}{ Long-term debt/Assets } & 0.002 & $0.149^{* * *}$ & 0.054 & $0.157^{* *}$ \\
\hline & $(0.046)$ & $(0.041)$ & $(0.059)$ & $(0.072)$ \\
\hline \multirow[t]{2}{*}{ Current assets/Assets } & 0.0656 & $-0.167^{* *}$ & 0.007 & $-0.237^{* *}$ \\
\hline & $(0.118)$ & $(0.073)$ & $(0.111)$ & $(0.091)$ \\
\hline \multirow[t]{2}{*}{$\ln$ (assets) } & $-0.076^{* * *}$ & $0.219^{* * *}$ & $-0.078^{* * *}$ & $0.205^{* * *}$ \\
\hline & $(0.011)$ & $(0.084)$ & $(0.013)$ & $(0.085)$ \\
\hline \multirow[t]{2}{*}{ Sales growth } & -0.037 & $0.248^{* * *}$ & -0.012 & $0.212^{* *}$ \\
\hline & $(0.117)$ & $(0.045)$ & $(0.091)$ & $(0.074)$ \\
\hline \multirow[t]{2}{*}{ Cash flow/Assets } & $-0.136^{* * *}$ & $-0.101^{*}$ & $-0.188^{* * *}$ & -0.081 \\
\hline & $(0.054)$ & $(0.062)$ & $(0.035)$ & $(0.075)$ \\
\hline \multirow[t]{2}{*}{${ }^{1}\{$ Dividend $>0\}$} & $-0.178^{* * *}$ & -0.028 & $-0.114^{* *}$ & -0.011 \\
\hline & $(0.067)$ & $(0.043)$ & $(0.057)$ & $(0.041)$ \\
\hline \multirow[t]{2}{*}{ TFP } & $-0.268^{* * *}$ & -0.070 & & \\
\hline & $(0.092)$ & (0.098) & & \\
\hline \multirow[t]{2}{*}{ Lagged TFP } & & & $-0.307^{* * *}$ & -0.121 \\
\hline & & & $(0.092)$ & $(0.091)$ \\
\hline
\end{tabular}

If the assessment removes $\mathrm{CC}$ when estimating productivity at the firm level, determining the capacity of the production function could be biased, especially if both employment and investment are measured; the data shows that both investment and employment are measurable (Beck, Demirgüç-Kunt, \& Maksimovic, 2005) that are negatively associated with FC. In this study, the results show that, if these EF and loans are excluded from all production functions and structural estimates, there is reduction in negative projections of capital and wages (Guiso et al., 2004). Tables 4 and 5 estimate the impact of TFP on CC alternatives available for firms. The key difference between the two estimations is that, in Table 4, the TFP was estimated independently from FC, whereas the estimations in Table 5 also present the influence of FC on TFP inputs.

In both of the tables it can be seen that the CC is found to be significant. Moreover, the TFP and lagged TFP measures are also significant. These results indicate that the productivity of firms is affected if CC are applied. These limits influence the decision making, loan receiving, and investment planning of businesses. As SMEs are responsible for half the business output in Canada, CC and FC applied to these businesses need to be reduced so that productivity can be improved.

\begin{tabular}{l|c|c|c|c}
\hline \multicolumn{7}{c}{ Table 5. Estimate the impact of TFP on credit } \\
\cline { 4 - 5 } & $(\mathbf{1})$ FC & & $\mathbf{( 2 )}$ & \\
\cline { 4 - 5 } & & Need Fin & FC & Need Fin \\
\hline Current debt/Assets & $0.191^{* * *}$ & $0.262^{* * *}$ & $0.193^{* * *}$ & $0.264^{* * *}$ \\
\hline Long-term debt/Assets & $(0.073)$ & $(0.052)$ & $(0.055)$ & $(0.041)$ \\
\hline & 0.025 & $0.158^{* * *}$ & 0.015 & $0.174^{* * *}$ \\
\hline Current assets/Assets & $(0.037)$ & $(0.054)$ & $(0.055)$ & $(0.051)$ \\
\hline & 0.046 & $-0.184^{* *}$ & 0.038 & $-0.187^{* *}$ \\
\hline ln(assets) & $(0.123)$ & $(0.087)$ & $(0.116)$ & $(0.081)$ \\
\hline & $-0.149^{* * *}$ & $0.181^{* *}$ & $-0.107^{* * *}$ & $0.232^{* * *}$ \\
\hline Sales growth & $(0.012)$ & $(0.071)$ & $(0.012)$ & $(0.072)$ \\
\hline & 0.017 & $0.224^{* * *}$ & -0.054 & $0.204^{* * *}$ \\
\hline Cash flow/Assets & $(0.091)$ & $(0.053)$ & $(0.099)$ & $(0.062)$ \\
\hline & $-0.185^{* * *}$ & $-0.084^{*}$ & $-0.149^{* * *}$ & -0.079 \\
\hline $1\{$ Dividend $>0\}$ & $(0.052)$ & $(0.047)$ & $(0.042)$ & $(0.061)$ \\
\hline & $-0.191^{* * *}$ & -0.017 & $-0.171^{* *}$ & -0.021 \\
\hline TFP & $(0.065)$ & $(0.027)$ & $(0.089)$ & $(0.041)$ \\
\hline Lagged TFP & -0.032 & $-0.135^{* *}$ & & \\
\hline & $(0.087)$ & $(0.072)$ & & \\
\hline
\end{tabular}

\section{Discussion and Conclusion}

By incorporating exclusive data on investment procedures and results from SMEs in Canada, we have concluded that companies will be forced towards EF, which reflects the financial struggles of borrowing businesses. The benefit of our measurement is that it separates the need for EF from the possibility of having to borrow, which was missing from previous studies (De Nicolò \& Juvenal, 2014). Businesses with a high cash-flow to assets ratio are less likely to need financial support, although they would be forced to do so if necessary. Following previous studies, the results of this study have managed to resolve two arguments: first, the fact that the use of cash flow sensitivity of investment can be used as indirect evidence of friction in the credit market, and second, that the result 
of such sensitivity can be a model without financial problems. Our assessment suggests that these two arguments only partially capture the role of cash flow (Bena \& Jurajda, 2011). Higher levels of investment and cash flow can be generated through higher productivity levels. SMEs do not need EF, such as high productivity. The main cash flow shows that the company's financial position is stable and can provide a high level of investment support to firms. The results of the present study are supported by recent and past literature. Cao \& Leung (2019) used a similar approach to the one applied in this study in order to evaluate the impact of CC on firm productivity in Canada. The findings have shown that, if constraints are put on the credit ability of SMEs, they risk limiting their growth. Chen and Guariglia (2013) and Yang (2018) studied the influence of FC on the productivity of the firm. The findings also suggest that productivity is affected in private firms and other firms with lower liquidity, due to the limited availability of internal and EF. The availability of finance is extremely important for the long-term productivity of organizations, and limiting the credit availability of SMEs hinders their opportunity to grow (Amos \& Zanhouo, 2019; Bremus \& Fratzscher, 2014; Coad, Pellegrino, Savona, \& Technology, 2016).

In the SFSME data, companies report whether or not they applied for EF, and if they have, what the results were. The types of financing include long- and short-term loans, lease financing, government grants, equity, and trade credit. Our results also found that, if the estimated coefficient of labor and capital are omitted, estimates of capital regulations and wages in production funds can increase productivity constraints and decrease the $\mathrm{CC}$. There is a negative relationship between input and productivity estimates, and this downward bias leads to an upward bias. The estimates were negatively correlated with negative credit barriers, without correcting for bias.

\section{Research Implications and Limitations}

The results of this study have certain policy applications. Our research has found that governments want to keep its strategy in situations where small businesses are subsidized on productivity. In terms of EF, if small companies have a large production capacity but cannot grow, this contributes to the overall production loss. However, government assistance can help to increase the overall productivity of a firm by overcoming financial difficulties. Such a policy could have a long-term effect on the growth of the economy. A strategy that only depends on the size of the company is less effective, as some small companies are less productive, and these strategies may not necessarily help them overcome financial difficulties and grow. SMEs improve their performance in terms of the firm's potential. Liquidity reduction policies are effective in helping SMEs avoid financial pressures. The demand for foreign aid is determined by the need for investment and employment, which is, in turn, a major blow to productivity. In order to assess the possibilities of economic coercion and production processes in the economic system, it is necessary to evaluate a fully defined dynamic model of investment and financing, which includes the FC theory.

\section{References}

Ackerberg, D. A., Caves, K., \& Frazer, G. (2015). Identification properties of recent production function estimators. Econometrica, 83(6), 24112451. Available at: https://doi.org/10.3982/ecta13408.

Aghion, P., Bergeaud, A., Cette, G., Lecat, R., \& Maghin, H. (2019). Coase lecture-the Inverted-urelationship between cedit access and productivity growth. Economica, 86(341), 1-31. Available at: https://doi.org/10.1111/ecca.12297.

Al-Haddad, S., Taleb, R. A., \& Badran, S. (2018). The impact of the education services quality on students' satisfaction: An empirical study at the business schools in Jordan. International Journal of Business Excellence, 14(3), 393-413. Available at: https://doi.org/10.1504/ijbex.2018.10010423.

Altomonte, C., Gamba, S., Mancusi, M. L., \& Vezzulli, A. (2016). R\&D investments, financing constraints, exporting and productivity. Economics of Innovation and New Technology, 25(3), 283-303. Available at: https://doi.org/10.1080/10438599.2015.1076203.

Amos, S., \& Zanhouo, D. A. K. (2019). Financial constraints, firm productivity and cross-country income differences: Evidence from subSahara Africa. Borsa Istanbul Review, 19(4), 357-371.

Bannerman, S., \& Fu, G. (2019). Analyzing access to long term debt effects on firms growth: Evidence of China. European Journal of Social Sciences, 58(1), 5-13.

Beck, T., Demirgüç-Kunt, A., \& Maksimovic, V. (2005). Financial and legal constraints to growth: Does firm size matter? The Journal of Finance, 6O(1), 137-177. Available at: https://doi.org/10.1111/j.1540-6261.2005.00727.x.

Bena, J., \& Jurajda, Š. (2011). Financial development and corporate growth in the EU single market. Economica, 78(311), 401-428. Available at: https://doi.org/10.1111/j.1468-0335.2009.00822.x

Bilal, A. R., Khan, A. A., \& Akoorie, M. E. M. (2016). Constraints to growth: A cross country analysis of Chinese. Indian and Pakistani SMEs. Chinese Management Studies, 1O(2), 65-386. Available at: https://doi.org/10.1108/cms-06-2015-0127.

Bokpin, G. A., Ackah, C., \& Kunawotor, M. E. (2018). Financial access and firm productivity in Sub-Saharan Africa. Journal of African Business, 19(2), 210-226.

Bolton, P. (2016). Presidential address: Debt and money: Financial constraints and sovereign finance. The Journal of Finance, $71(4)$, 14831510

Bremus, F., \& Fratzscher, M. (2014). Drivers of structural change in cross-border banking since the global financial crisis. Journal of International Money and Finance,52, 32-59.

Buallay, A., Hamdan, A., \& Zureigat, Q. (2017). Corporate governance and firm performance: Evidence from Saudi Arabia. Australasian Accounting, Business and Finance Journal, 11(1), 78-98. Available at: https://doi.org/10.14453/aabfj.v11i1.6.

Calic, G., Shevchenko, A., Ghasemaghaei, M., Bontis, N., \& Tokcan, Z. O. (2020). From sustainability constraints to innovation. Sustainability Accounting, Management and Policy Journal, 1 1(4), 695-715. Available at: https://doi.org/10.1 108/sampj-02-2019-0084.

Cao, S., \& Leung, D. (2019). Credit constraints and productivity of SMEs: Evidence from Canada. Economic Modelling, 88, 163-180. Available at: https://doi.org/10.1016/j.econmod.2019.09.018.

Chatterjee, P., Karray, S., \& Sigué, S. P. (2019). Cooperative advertising programs: Are accrual constraints necessary? International Transactions in Operational Research, 26(6), 2230-2247. Available at: https://doi.org/10.1111/itor.12431.

Chen, M., \& Guariglia, A. (2013). Internal financial constraints and firm productivity in China: Do liquidity and export behavior make a difference? Journal of Comparative Economics, 41(4), 1123-1140.

Choi, S., Furceri, D., Huang, Y., \& Loungani, P. (2018). Aggregate uncertainty and sectoral productivity growth: The role of credit constraints. Journal of International Money and Finance, 88, 314-330.

Coad, A., Pellegrino, G., Savona, M. J. E. o. I., \& Technology, N. (2016). Barriers to innovation and firm productivity. Economics of Innovation and New Technology, 25(3), 321-334. Available at: https://doi.org/10.1080/10438599.2015.1076193.

Dasgupta, S., Li, E. X., \& Yan, D. (2017). Inventory behavior and financial constraints: Theory and evidence. Paper presented at the Paper presented at the Asian Finance Association (AsianFA) 2014 Conference Paper.

De Nicolò, G., \& Juvenal, L. J. J. o. f. s. (2014). Financial integration, globalization, and real activity. Journal of Financial Stability, 10, 65-75. Available at: https://doi.org/10.1016/j.jfs.2013.04.004. 
Dinopoulos, E., Kalyvitis, S., \& Katsimi, M. (2020). Variable export price elasticity, product quality, and credit constraints: Theory and evidence from greek firms. Journal of International Money and Finance, 104, 102135. Available at: https://doi.org/10.1016/j.jimonfin.2020.102135.

Dörr, S., Raissi, M., \& Weber, A. (2018). Credit-supply shocks and firm productivity in Italy. Journal of International Money and Finance, 87, 155-171. Available at: https://doi.org/10.1016/j.jimonfin.2018.06.004.

Dubé, J., Brunelle, C., \& Legros, D. (2016). Location theories and business location decision: A micro-spatial investigation of a nonmetropolitan area in Canada. Review of Regional Studies, 46(2), 143-170.

Eapen, A., Yeo, J., \& Sasidharan, S. (2019). Finance constraints and technology spillovers from foreign to domestic firms. Economic Modelling, 76, 50-62. Available at: https://doi.org/10.1016/j.econmod.2018.07.019.

Ganau, R. (2016). Productivity, credit constraints and the role of short-run localization economies: Micro-evidence from Italy. Regional Studies, 5o(11), 1834-1848. Available at: https://doi.org/10.1080/00343404.2015.1064883.

Guiso, L., Jappelli, T., Padula, M., \& Pagano, M. (2004). Financial market integration and economic growth in the EU. Economic Policy, 19(40), 524-577. Available at: https://doi.org/10.1111/j.1468-0327.2004.00131.x.

Hasan, S., \& Sheldon, I. (2016). Credit constraints, technology choice and exports: A firm-level study for Latin American countries. Review of Development Economics, 2O(2), 547-560. Available at: https://doi.org/10.1111/rode.12248.

Hasan., I., Kobeissi, N., Liu, L., \& Wang, H. (2018). Corporate social responsibility and firm financial performance: The mediating role of productivity. Journal of Business Ethics, 149(3), 671-688. Available at: https://doi.org/10.1007/s10551-016-3066-1.

Jin, M., Zhao, S., \& Kumbhakar, S. C. (2019). Financial constraints and firm productivity: Evidence from Chinese manufacturing. European Journal of Operational Research, 275(3), 1139-1156.

Kraja, Y. B. (2018). The impact of tangible and intangible assets on the SMEs' success: the Albanian case. In entrepreneurship in postcommunist countries (pp. 135-145): Springer.

Li, Y. A., Liao, W., \& Zhao, C. C. (2018). Credit constraints and firm productivity: Microeconomic evidence from China. Research in International Business and Finance, 45, 134-149. Available at: https://doi.org/10.1016/j.ribaf.2017.07.142.

Lucey, B. M., Zhang, Q. J. J. o. B., \& Finance. (2011). Financial integration and emerging markets capital structure. Journal of Banking Eீ Finance, 35(5), 1228-1238. Available at: https://doi.org/10.1016/j.jbankfin.2010.10.017.

Miao, J., \& Wang, P. (2018). Asset bubbles and credit constraints. American Economic Review, 108(9), 2590-2628. Available at: https://doi.org/10.1257/aer.20160782.

Moscalu, M., Girardone, C., \& Calabrese, R. J. J. O. S. B. M. (2019). SMEs' growth under financing constraints and banking markets integration in the euro area. Journal of Small Business Management, 58(4), 707-746. Available at: https://doi.org/10.1080/00472778.2019.1668722.

Olley, G. S., \& Pakes, A. (1992). The dynamics of productivity in the telecommunications equipment industry (No. w3977). National Bureau of Economic Research.

Ortiz-de-Mandojana, N., \& Bansal, P. (2016). The long-term benefits of organizational resilience through sustainable business practices. Strategic Management Journal, 37(8), 1615-1631. Available at: https://doi.org/10.1002/smj.2410.

Ramkissoon, H., \& Mavondo, F. T. (2017). Proenvironmental behavior: Critical link between satisfaction and place attachment in Australia and Canada. Tourism Analysis, 22(1), 59-73. Available at: https://doi.org/10.3727/108354217x 14828625279735.

Rispoli, L., Leung, D., \& Baldwin, J. (2013). Canadian labour productivity differences across firm size classes, 2002 to 2008. The Canadian Productivity Reviere.

Rose, J. B. (2016). Constraints on public sector bargaining in Canada. Journal of Industrial Relations, 58(1), 93-110. Available at: https://doi.org/10.1177/0022185615598189.

Wetzel, P., \& Hofmann, E. (2019). Supply chain finance, financial constraints and corporate performance: An explorative network analysis and future research agenda. International Journal of Production Economics, 216, 364-383. Available at: https://doi.org/10.1016/j.ijpe.2019.07.001.

Yang, W. (2018). Empirical study on effect of credit constraints on productivity of firms in growth enterprise market of China. Journal of Finance and Economics, 6(5), 173-177. 